\title{
Consumer Justice: A Symbol of Economic Prosperity and Social Progressiveness
}

\author{
Subir Kumar Roy \\ Law Department, Bankura University \\ Main Campus, Block II, P.O.- Purandarpur, Bankura, West Bengal 722155, India \\ Tel./Fax: +91-3242-201-129 E-mail:_dr.roysubir@gmail.com \\ Submitted: Jul 23, 2016; Reviewed: Jul 29, 2016; Accepted: Aug 4, 2016
}

\begin{abstract}
It is well recognized fact that consumer confidence and trust in a well functioning market for financial services promotes financial stability, growth efficiency and innovation over the long term. So protection of the interest of consumers is not merely an ethical or humanitarian issue rather it is also an issue of economy. Consumer protection demands for setting of minimum quality specification and safety standards for goods and services to curb unfair trade practices. So far the international norms are concerned it effectively contains the Bill of Rights of Consumers which help them across the globe to effectively protect their interests. Keeping in consideration about the poor bargaining position of the consumers and with an aim to ensure consumers to access non-hazardous products United Nation issued Guidelines for Consumer Protection, 1985, expanded again in 1999. The consumer justice is a facet of socio- economic justice and emanates from the basic philosophy of the Indian constitution i.e. to do justice and to strengthen the standard and status of the people of this country. It has been discussed in this article in an elaborate way about the various provisions of the Constitution and all the legislations which addresses the issues of consumers and resolve to protect their interests. But still the exploitation of Indian consumers by the dishonest traders and service providers become a routine matter and this article also scanned the reasons for the same and also provides suggestions to ameliorate the conditions of consumers. This paper is based on qualitative analysis of the information mainly obtained from secondary sources such as different books and journals as referred over here, Policy documents, existing laws, reports of United Nations, important judgments and observations of Judiciary etc.
\end{abstract}

Keywords: Bill of Rights; Consumer Empowerment; Consumer Protection; Financial Stability

DOI: http://dx.doi.org/10.20956/halrev.v1n2.302

\section{INTRODUCTION}

Consumer protection not only involve the protection of consumers from the abuse what they suffer in marketplace but also the empowerment of consumers through informed choice. No doubt, the prime concern of consumer protection is to uphold the economic interest of the consumers but gradually the above concept is being overshadowed by the idea of strengthening consumer protection mechanism so as to effectively deal with the grievances of 
consumers and to improve their position in their dealings with the business community. The consumers are the backbone of the growth of economy of a country and an adequate consumer protection boosts the economy further. So, consumer welfare should be the paramount importance of the policy of consumer protection.

Consumer protection is a means to arm the poor bargaining power of the consumers against the traders or service providers who are united, strong and posses the power of dominance. As a resultant the consumers are often exploited with respect to quality, short weight, measurement, defective and adulterous goods, defective service etc. due to the unfair trade practices adopted by the dishonest traders and service providers. United nations through its guidelines for consumer protection (as expanded in 1999) ${ }^{1}$ recognised that consumers often face imbalance in economic terms, educational level and bargaining power and endorses the right of the consumers to access non-hazardous products as well as the right to promote just, equitable and sustainable economic and social development and environmental protection.

The General Assembly recognised that consumer confidence and trust in a well functioning market for financial services promotes financial stability, growth efficiency and innovation over the long term and for the above it has given importance on consumer protection by ensuring that Consumer protection should be an integral part of the legal, regulatory and supervisory framework,

United Nations Guidelines for Consumer Protection (as expanded in 1999), United nations, New York, 2003, available at www.un.org/esa/sustdev/publications/ consumption_en.pdf (Accessed 20/05/2016). and should reflect the diversity of national circumstances and global market and regulatory developments. ${ }^{2}$ General Assembly gave stress on the need of effective consumer legislation, strengthening of consumer protection enforcement agencies to redress the grievances of the consumers, to enhance financial consumer protection. ${ }^{3}$

General Assembly has also highlighted the matter of electronic commerce which offer consumers new and substantial benefits, including convenience, access to a wide range of goods and services, and the ability to gather and compare information about such goods and services but at the same time cautioned that it may put the interest of the consumers at peril due to the reasons of its fastness and easiness unless the consumers will be informed about their rights and obligations in the electronic market places in a proper way.

Consumer protection denotes about setting of minimum quality specification and safety standards for goods as well as of services and a legal mechanism which will keep a vigil on market so as to protect the customers from unfair trade practices, anticompetitive agreements, activities related to abuse of dominance of big market players etc as well as to redress the grievances of the people. The protection of consumers' interest is directly linked with the economic prosperity of a nation and also an indicator of the progressiveness of civil society.

\footnotetext{
Draft resolution on consumer protection (United Nations Conference on Trade and Development, 2015) for consideration by General Assembly, available at http://unctad.org/meetings/en/SessionalDocuments/ ditc-ccpb2015 02res en.pdf (Accessed 19/05/2016). Ibid.
} 


\section{ANALYSIS AND DISCUSSION}

Bill of Rights of Consumer: An International Approach

Mr. John F. Kennedy, the $25^{\text {th }}$ President of USA became the symbol of liberty by his most memorable speech in the way of 93-special message to the Congress of the United States where he proclaimed the definition of consumer as which 'include us all' who formed largest economic group in the economy affecting and affected by almost every public and private economic decision. ${ }^{4} \mathrm{He}$ considered the consumers as largest and one of the important groups of economy but they are not heard in policy or economic matters as they are scattered and not effectively organised. Kennedy was very conscious regarding the protection of the interest and fulfillment of the needs of the consumers. He was of opinion 'if consumers are offered inferior products, if prices are exorbitant, if drugs are unsafe or worthless, if the consumer is unable to choose on an informed basis, then his dollar is wasted, his health and safety may be threatened, and the national interest suffers". ${ }^{5}$

He wanted to chanalise the income of the customers in a proper way so that ultimately they can generate income and ensure the well being of most of the families. He had drawn the attention of the Congress towards the advent of the technologies, which according to him has created problem for the consumers as it provided increasing varieties of goods and services, most of which are

\footnotetext{
4 See: John F. Kennedy. "Special Message to the Congress on Protecting the Consumer Interest". March 15, 1962. Online by Gerhard Peters and John T. Woolley, The American Presidency Project. http://www.presidency. ucsb.edu/ws/?pid=9108 (Accessed 21/05/2016).

5 Ibid.
}

new and sophisticated and due to the lack of information as to the quality, quantities, efficacy and properties of these products and services the consumers are simply being misled and deceived. According to him marketing is increasingly impersonal and advertisement is affecting the choice of the consumers. He was in favour of an effective and strong legislation along with independent regulatory agencies to protect the health, money and security of the consumers. For that end he proclaimed four rights of the consumers: ${ }^{6}$ i) the right to choose; ii) the right to information; iii) the right to safety; and iv) the right to be heard.

Over the time the consumer movement intensified across the globe which consolidated the position of consumers against the dishonest traders and also enhances their awareness against unfair trade practices. The world polity under the aegis of consumer International ${ }^{7}$ added four more rights with the rights proclaimed by Mr. Kennedy, the than President of USA, which are as follows: 1) the right to satisfaction of basic needs; 2) the right to redress; 3 ) the right to consumer education; and 4) the right to a healthy environment.

Now these eight basic consumer rights are considered as Bill of Rights of Consumers which helps the consumer across the globe to effectively protect their interests.

\footnotetext{
Ibid.

Consumer International is founded in 1960 as the world federation of consumer groups. It claims that it fights for a fair, safe and sustainable future for all consumers in a global marketplace increasingly dominated by international corporations. Consumer International has 240 member organisations in 120 countries. Its mission is to champion Consumer Rights internationally in order to help protect and empower consumers everywhere. For details see, http://www.consumersinternational.org/ who-we-are/consumer-rights/ (accessed 22/05/2016)
} 
The general assembly through its resolution 39/248 adopted guidelines for consumer protection by consensus on 9 April 1985 . The above guidelines provide a framework for Governments especially in developing countries to incorporate consumer protection policies and legislation. In late 1970s the Economic and Social Council recognized that consumer protection had an important impact on economic and social development and after that in 1977, the Council asked the Secretary-General to make a survey of national institutions and legislation regarding consumer protection. After that the Council prepared a comprehensive report on consumer protection in the year 1979 for the consideration of the Governments and for making an international framework for consumer protection the Secretary General started to consult with the Governments of different states.

Accordingly, the Secretary General submitted draft guidelines for consumer protection to the Economic and Social Council in 1983 and finally the Guidelines were issued in 1985. Keeping in consideration about the poor bargaining position of the consumers and with an aim to ensure consumers to access non-hazardous products as well as to promote just, equitable and sustainable economic and social development and environmental protection United Nations Guidelines for Consumer Protection, 1985 (as expanded in 1999) issued with the following objects:

1. To assist countries to protect their consumers

2. To make production and distribution pattern responsive towards the demands of consumers
3. To encourage high level of ethical standard of the traders and service providers

4. To assist the countries in restraining of abusive business practices

5. To promote in creation of independent consumer groups

6. To promote international solidarity for consumers' protection

7. To promote such market condition which will allow consumers with greater choice at lower price

8. To promote sustainable consumptions United Nations Guidelines for Consumer Protection, 1985 (as expanded in 1999) encourages the Governments to incorporate a strong consumer policy in tune with their own economic, social and environmental circumstances of the country in order to meet the legitimate demands of their consumers, to protect them from hazards, to protect their economic interest, to create informed consumers, to provide consumer education, to constitute effective redress mechanism to resolve consumer grievances, to promote sustainable consumption pattern, to facilitate the opportunity so that the consumers or their organisations may attach with the decision making process, etc.

However, the governments must ensure that their initiatives for consumers' protection shod not create any hinderance to international trade and business. Governmental policies should ensure physical safety as well as promotion and protection of economic interest of consumers. The governments should be responsive and careful enough to ensure that consumers should get only safe and quality products and for that 
end there should be proper vigil in market and availability of facilities to test and certify the safety, quality and performance of essential consumer goods and services. ${ }^{8}$

The revised guideline adopted by the General Assembly plenary on the proposal of the Seventh United Nations Conference on Trade and Development, 2015 establishes certain principles for good business practices for conducting online and offline transaction with the customers: ${ }^{9}$ a) Businesses should deal fairly and honestly with the consumers; b) Consumers should not be subjected to deceptive and unfair or unethical trade practices; c) Ensuring disclosure and transparency; d) Businesses engaged in online and off-line commerce should protect personal information through appropriate control and security mechanisms; e) Consumers should have the liberty to access adequate, affordable and just complaints handling mechanisms based on the rule of law; f) Précised policy to handle the situation of conflict of interest; and g) All sorts of transaction should comply with consumer laws and regulations.

\section{Consumer Protection from the Prism of Indian Legal System}

Due to illiteracy, poverty, lack of awareness etc. the Indian consumers are easily deceived and hackled. The exploitation of Indian consumers by the dishonest traders and service providers become a routine matter. The mal practices like unfair trade practices, anti-

8 Aarne Puisto \& Hamed Alavi (2016). "Abuse of Dominant Market Position by Predatory Pricing; The Valio Case". Hasanuddin Law Review, 1(1), 24-37.

9 Charles E. F. Rickett and Thomas G. W. Telfer (eds). (2003). International Perspectives on Consumers' Access to Justice. Cambridge, GB: Cambridge University Press. competitive agreements, abuse of dominance, monopolistic attitude, predatory price, false representation as to the quality, quantity, price, usefulness or effectiveness of the goods, misleading advertisement, etc. become the reasons for the sufferings of the Indian consumers. Here, the problems of the consumers intensified due to the absence of a comprehensive consumer policy, lack of vigil of regulatory authorities on market, corruption etc. Often the consumers are provided such goods or services in lieu of consideration which are hazardous to their life and property. But like any other society, in India also the consumers are the soul of the economic structure and certainly the legal mechanism of this country cannot overlook the plight of the customers, we have quite fair numbers of legislations which contains the salutary provisions to protect the rights of the consumers.

\section{Indian Constitution and Consumer Protec- tion}

The Indian constitution is considered as supreme law of the land and it ensures the tripartite picturesque of justice in the field of social economy and political to 'We the people of India.' The analogy what is being deduced from the above mandate is that the consumers which includes ourselves are also empowered to have the quality goods and services of excellence in an ideal environment of economic transactions where they can get the information as to the properties and price of goods, can use their option of choice with proper mechanism of redressing their grievances. No doubt, the consumer justice is a facet of socio-economic justice 
and emanates from the basic philosophy of the constitution i.e. to do justice and to strengthen the standard and status of the people of this country. The incorporation of the words like Justice, Liberty, Freedom etc. in the Preamble are not merely the jugglery of words rather mandates towards the creation of a welfare state and certainly without induction of a mechanism to wipe out the tears of the consumers it cannot become welfare state. ${ }^{10}$

The introduction of the word 'socialism' in the constitution by $42^{\text {nd }}$ Amendment Act made in the year 1976 revels the intention of the law makers to go with Nehru economic model i.e. mixed economy. Though mixed economy does not restrict monopoly like market economy but certainly favours a system whereby few should not dominate all. This statement gets further impetus from Art. 39(b) \& 39(c) of the Indian Constitution which mandates that it is the cardinal duty of the state to ensure that the resources of this country should not be accumulated into the hands of few and state must ensure that these resources should be used for the welfare of the people of this country. The above provision of the Constitution not only advocates for distributive justice rather it also advocates against the black economy. The major source of black economy is the unfair, unethical and deceptive practices of the corrupt market players for whom the consumers have to bear the pain.

Apart from above, Art.14 is there in the Constitution which mandates for 'Equality before Law' and 'Equal Protection of

\footnotetext{
10 K. Madhusudhana Rao. (2015). Cases and Materials on the Consumer Protection Act, 1986. Asia Law House, Cochin, Kerala, pg. 32
}

Law'. Both these phraseologies take the colour from each other and the underlying idea is that like should be treated alike not the unlike. We know that Art.14 prohibits class legislation and not the reasonable classification which should be based on intelligible differentia and since E.P. Royappa case it become settled rule that arbitrariness is antithetic to equality means when arbitrariness comes equality goes out. It is axiomatic from the above proposition that Art.14 has an inseparable connection with 'Rule of Law' i.e. all are subjected under the law of the land, which clarifies that state is obliged to confer 'equality of status' on all including on consumers and to ensure that unscrupulous traders should abide by the laws, norms and regulations of the land which automatically will curb the exploitative mind of the traders. ${ }^{11}$ One of the important imperatives of Art.14 is the doctrine of legitimate expectation which gives guarantee to consumers to be treated fairly during their transaction with the traders or service providers for consuming the goods or availing services.

'The right to know' is a basic postulate of Art.19 (1) (a) of the Indian Constitution because without having knowledge or information it is impossible to form any opinion or share the views with others. 'Right to know' has not only the importance in the field of governance rather it is considered as a most effective and salutary provision to ensure the rights of the consumers. The consumers should have the liberty and right to know about the quality, standard, price, quantity, efficacy, potentiality, usefulness,

\footnotetext{
11 Peter Asch. (1988). Consumer Safety Regulation. Putting a Price on Life and Limb. USA: Oxford University Press, pg. 87
} 
contents or properties of the goods or service at the time of entering into the contract for commercial transactions otherwise they may be deceived by dishonest traders by taking the opportunity of their ignorance and unawareness. Similarly advertisement has been considered as an important aspect of freedom of speech and expression because it enable the consumers to get information of various commodities, articles and services from which they can make a comparative analysis as to the price, quality etc. of the goods and services and after that can select the best one for them or which suited to them more.

Art.19 (1) (g) guarantees a right to all the citizens to carry on any occupation, trade or business but subjected to 'reasonable restrictions' provided under Art.19 (6) of the Constitution of India. The above provisions of the Constitution clearly mandates that the traders or service providers have no unfettered rights to involve in any kind of business of their personal whims or mores or only on the ground of their economic interests rather they have to be responsive and careful towards the physiological and mental health, comfort, money etc. The above provision also clarifies that no one should be allowed to carry on such trade, business or profession which is hazardous to the life of the people or is otherwise dangerous or immortal.

Art.21 of the Indian constitution gives the guarantee of the most important and dearest right to the people i.e. the right to life and personal liberty. Spurious, defective or unhygienic goods and services may prove fatal for the life of the people and that is why prohibited under Art.21 of the Constitution.
Article 38(1) of the Constitution bestows responsibility upon the State to promote the welfare of the people by securing and protecting a social order in which social, economic and politicaljustice can be informed to all. Art. 39 impose the responsibility on states to ensure that the workers should not be compelled to compromise with their health and strength due to their economic necessity. Art. 39A mandates for incorporating such legal system which will promote justice to all and it is the duty of the State to ensure that justice should not denied to any citizen by reason of economic or other disability. It clearly postulates that justice cannot be denied to consumers in India. By virtue of Art.46 of the Constitution the State is under the legal obligation to end all forms of exploitation and Art.47 imposes the responsibility on State to raise the standard of living. Both these Art.46 and Art.47 can be used to ameliorate the conditions of the consumers.

The above provisions of the Constitution clarifies that it gives emphasis for having such political social, economic and legal order whereby the people as a whole which invariably includes the consumers also can live with dignity can save themselves from any kind of injustice, unfavorable condition of life, any kind of act of exploitation etc. The State has been entrusted with the duty to maintain public health and strength of the people which become possible only when State will take effective measure and keep strong vigil to ensure the complete ban on the supply of adulterous food; unhygienic products etc. and completely curb the unfair trade practices. 


\section{Laws Related to Consumers Protection in} India

In India we have a plethora of legislation to protect the interest of the consumers. Prior to the enactment of Consumer Protection Act, 1986 all other laws related to protection of consumers' interest were scattered one, formulated to deal with the different specified areas of interest of the consumers. Some of these laws are:

The Indian Contract Act, 1872 deals with the formation performance and enforcement of agreements and when the agreement will attain the status of contract. It explains the situation that when an agreement become void, voidable, illegal or a contract become void. It also provides the remedy against breach of contract.

Sale of Goods Act, 1930 deals with the laws relating to sale and purchase of goods. It specifies the duty and rights of the seller and purchaser of the goods as well as along with other matters provides the concept of 'Caveat Emptor' whereby the Seller is supposed to provide mercantile goods and at the same time state about 'buyer beware'.

Agriculture Products (Grading and Marking) Act, 1937 provides certificate of bearing quality products popularly known as "AGMARK"

Drugs and Cosmetic Act, 1940 has been enacted with a to import, manufacture, distribution and sale of drugs and cosmetics through licensing and only by the qualified persons, to regulate the manufacture and sale of Ayurvedic, Siddha and Unani drugs, to establish Drugs Technical Advisory Board and Drugs Consultative Committees to monitor the matters referred above for drug and cosmetics.

Essential Commodities Act, 1955 is enacted with a view to control production, supply, distribution etc. of essential commodities for maintaining or increasing supplies and for securing there equitable distribution with fair price to stop black market.

The Prevention of Food Adulteration Act, 1959 is enacted with an intention to prevent the sale of impure, unwholesome, adulterate foodstuffs.

The Drugs and Magic Remedies (Objectionable Advertisement) Act, 1954 aims to control the advertisement of drugs in certain case, to prohibit the advertisement for providing magical remedies which includes a talisman, mantra, kavacha, and any other charm of any kind which is alleged to possess miraculous powers for or in the diagnosis, cure, mitigation, treatment or prevention of any disease in human beings or animals or for affecting or influencing in any way the structure or any organic function of the body of human beings or animals, to prohibit the advertisement of certain drugs for treatment of certain diseases like procurement of miscarriage or conception in women, improvement of capacity of human beings to extend the sexual pleasure, correction of menstrual orders or the diseases, requires the immediate and timely treatment under the guidance of registered medical practitioners. It also prohibits the misleading advertisement as to the treatment of diseases through magical remedy.

The Cigarettes (Regulation of Production, Supply and Distribution) Act, 1975 provides for restrictions in relation to trade and commerce in, and production, supply 
and distribution of, cigarettes and for the allied matters.

So it is axiomatic from the above discussion that all the legislations which are discussed over here are piecemeal in approach deals with the specific areas but of course of important public interest. after gradual but in slow space the starting of the enlightened and vigilant consumer movement the urge is felt to have a comprehensive legislation to deal with the protection of the interest of consumer as a whole and in an uninterrupted manner i.e. the inbuilt mechanism should be there in the Act to redress the grievances of the people. Bearing the above ideas in mind the law makers enacted the Consumer Protection Act in the year 1986.

\section{Consumer Protection Act: Beginning of A} Concentrated Approach to Do Consumer Justice

The Consumer Protection Act, 1986 aims to promote and protect the rights of the consumers against the marketing of the commodities which are hazardous to their life and property, ensure the right to be informed about the quality, quantity, purity, effectiveness, usefulness, price etc., the right to be heard by the appropriate adjudicatory authorities to get the timely remedy and infuse awareness among consumers through consumer education.

As per the scheme of the Act any complainant can approach before the consumer redresses forums if that consumer has the allegation regarding: a) An unfair or restrictive trade practice being carried on by any trader or service provider; b) The goods bought by him is defective; c) The services hired suffered from deficiency; d) A trader or service provider has taken excess of charge; e) Goods which have been offered for sale is hazardous to life and safety; f) Services which have been offered, is hazardous to life and safety.

The Act defines Consumers which mean any person who buys any goods for a consideration, either which has been paid or partly paid, or purchased by way of deferred payment but does not include a person who purchase that goods for resale or for any other commercial purpose, or avails any services for a consideration, either which has been paid or partly paid, or purchased by way of deferred payment but does not include a person who avail a service for commercial purpose, or here it is needed to mention that any goods sold for the purpose of earning his or her livelihood for self- employment does not come within the term consumer.

The Act empowers the consumers to make complaint against the defective goods, or deficient services, spurious goods and unfair trade practices. Here defect ${ }^{12}$ means any fault, imperfection or shortcoming in the quality, quantity, potency, purity or standard in any goods required to be maintained under any law comes under the purview of defect. Deficiency ${ }^{13}$ means any fault, imperfection or shortcoming in the quality, quantity, potency, purity or standard in any service required to be maintained under any law. Service ${ }^{14}$ denotes service of any description which is made available to potential facilities in connection with banking. Financing insurance, transport, processing, supply of

\footnotetext{
Sec.2 (f) of Consumer protection Act, 1986

Sec. 2 (g) of Consumer protection Act, 1986

Sec.2 (o) of Consumer protection Act, 1986
} 
electrical or other energy, board or lodging, entertainment and information etc. but does not include any service rendered for free of charge o0r under a contract of personal service. Spurious goods and services ${ }^{15}$ means such goods and services which are claimed to be genuine but they are actually not so.

Unfair trade practices ${ }^{16}$ means a trade practice which is not fair and which adopted for promoting sale, use or supply of any goods or for the matter related to service and include any of the practices mentioned below:

a) Falsely represents that the goods are of particular quality, standard, style etc.

b) Falsely represents that the services are of particular quality, standard, style etc.

c) Falsely represents any second hand, rebuilt or old goods as new one;

d) Represents any goods have a particular benefit or sponsorship what it does not possess;

e) Falsely represents that the supplier has a sponsorship or approval

f) Falsely represents about the usefulness of a certain service;

g) Any warranty or guarantee is given without making proper test of goods or service;

h) Misleads the people about price of a goods or service

i) Gives advertisement of a goods or services, where false promise is made to offer the same in bargaining price or to offer gifts etc

j) Offer sale for spurious goods

15 Sec.2 (oo) of Consumer protection Act, 1986

16 Sec.2 (r) of Consumer protection Act, 1986
The Act constitutes the Consumer Protection Councils as well as the Consumer Redressal Forums to assist the consumers of this country and redress their grievances. The Act prescribes for central Consumer protection Council and State Consumer protection Council with an object to protect and promote the rights of consumers regarding following matters:

a) The right to be protected against the marketing of goods which are hazardous to life and property;

b) The right to be informed about the quality, quantity, purity, standard, price etc. of goods;

c) The right to be assured about variety of goods at competitive price;

d) To assure about protection of the interest of consumers in various forums;

e) Redressal against unfair trade practice;

f) The right to consumer education. The Act prescribes for District Forum, State Commission and National Commission to redress the grievances of the people. The District Forum can entertain the complaints related to a value of goods or service, not exceeding rupees twenty lakhs and confer with the power:

a) To remove the defects of the goods;

b) Replace the goods;

c) To return the complainant the price;

d) To stop the unfair or restrictive trade practices;

e) To cease the processing of spurious or impure goods;

f) To order for proper compensation for providing defective goods or service.

Any person aggrieved by the order of District forum may prefer appeal before the 
State commission but that should be made within 30 days from the passing of the order. However, delay may be condoned by the state commission if there remain sufficient reasons. The State Commission may entertain the complaints related to a value of goods or service exceeds rupees twenty lakhs but not exceed Rs. One crore and can entertain an appeal against the order of District Forum and may rectify the findings of the district forum.

National Commission entertains the complaints related to a value of goods or service exceeds Rupees One Crore and can entertain an appeal against the order of State Commission and may rectify the findings of the Commission. Any person aggrieved by the order of National Commission may prefer appeal before the Supreme Court but that should be made within 30 days from the passing of the order. However, delay may be condoned by the Supreme Court if there remain sufficient reasons.

The Act prescribes the limitation period according to which the District Forum, State Commission or National Commission cannot entertain any complaint unless the complaint has been filed within two years from the date of arising of cause of action. However sufficient reason against delay can be considered and condoned.

Consumer protection Act and The Competition Act is considered as two wings of a same apartment because the philosophy of both the laws is to promote welfare of the consumers. Both the Acts intends to hammer on the unequal relationships between consumers and traders or service providers.
In India the Competition Act mainly focuses upon: 1) Prohibition of anti-competitive agreements; 2) Prevention of Abuse of Dominant position; 3) Regulation of combinations; and 4) Establishment of Competition Commission of India to keep vigil on the market in order to restrain monopoly and to create a culture of competition in market

\section{CONCLUSION}

No doubt, the Consumer Protection Act, 1986 as amended in the year 2000 contains the salutary provisions to protect the interest of consumers but in reality failed to achieve the desired aims. It utterly failed to strengthen the consumer movement against the dishonest traders as well as failed to curb the unfair trade practices. The Act seems more punitive than preventive. Due to illiteracy, poverty, ignorance till now the consumers bargaining power remains week comparing to traders.

The Act no doubt prescribes simple procedure to lodge complaint before the three tires Redressal forum as mentioned above but that is only from the perception of advance section of the society because still a large chunk of people do not know how to fight their legal wages. The Act itself has certain inherent flaws like companies do not come within consumer under the Act due to the definition of consumer in the Act. It does not contain the elaborate provisions as to deal with e-transactions.

Hopefully the consumer protection Bill, which has been introduced on August 10, 2015, contains the provisions of online transactions, for setting up Central Consum- 
er Protection Authority which will among its vast activities, inquire into violations of consumer rights, investigating and launching prosecution at the appropriate forum and can declare a contract as void one. It imposes product liability on manufacturer for any loss if occurs to consumers due to use of a product. It introduces mediation as a mode of resolving the consumer dispute and proposes to penalty for imprisonment from one month to three years, or with a fine from 10,000 rupees to 50,000 rupees for violation of any provisions of the Act.

We have laws, we will have many more laws in near future but the need of the hour is to have strong political will to stringently implement the provisions of the laws. Country also requires proper education and awareness programmes for consumers to bargain with the unscrupulous traders and service providers by keeping eyes on eye. This can only do a complete justice with the Consumers.

\section{BIBLIOGRAPHY}

Aarne Puisto \& Hamed Alavi (2016). "Abuse of Dominant Market Position by Predatory Pricing; The Valio Case". Hasanuddin Law Review, 1(1), 24-37.

Charles E. F. Rickett and Thomas G. W. Telfer (eds). (2003). International
Perspectives on Consumers' Access to Justice. Cambridge, GB: Cambridge University Press.

Draft resolution on consumer protection (United Nations Conference on Trade and Development, 2015) for consideration by General Assembly, available at http://unctad.org/meetings/en/SessionalDocuments/ditcccpb2015 02res_en.pdf (Accessed 19/05/2016).

John F. Kennedy. "Special Message to the Congress on Protecting the Consumer Interest". March 15, 1962. Online by Gerhard Peters and John T. Woolley, The American Presidency Project. http://www.presidency. ucsb.edu/ws/?pid=9108 (Accessed 21/05/2016).

K. Madhusudhana Rao. (2015). Cases and Materials on the Consumer Protection Act, 1986. Asia Law House, Cochin, Kerala.

Peter Asch (1988). Consumer Safety Regulation. Putting a Price on Life and Limb. USA: Oxford University Press.

United Nations Guidelines for Consumer Protection (as expanded in 1999), United nations, New York, 2003, available at: www.un.org/esa/sustdev/publications/consumption en.pdf (Accessed 20/05/2016). 